\title{
Congenital heart diseases and pulmonary hypertension among Down syndrome pediatric patients
}

\author{
Khaleel.I ALSUWAYFEE*, Mohammed Essmat. AILBU-DAWLAH ${ }^{\star *}$, Qusay Norry. MOHAMMED** \\ *Department of pediatrics. College of medicine. Ninevah University, ** Department of pediatrics. \\ Alkhansaa teaching hospital. Mosul .Iraq \\ Correspondence: Khalilalhadidy@yahoo.com
}

(Ann Coll Med Mosul 2020; 42 (1):50-56).

Received: $18^{\text {th }}$ April 2020; Accepted: $13^{\text {th }}$ May 2020.

\section{ABSTRACT}

Background: Down syndrome (DS) is the commonest chromosomal abnormality with high incidence of congenital heart diseases (CHDs). The most prevalent two CHD among DS children.in most studies are complete atrioventricular canal (CAVC) (also called atrioventricular septal) defect and atrial septal defects (ASD). There is high incidence of pulmonary arterial hypertension (PAH) among DS children with CHD compared to non Down syndrome (NDS) children.

Aims: To measure the prevalence of CHD in general and the relative frequency of different types of CHD among DS children as well as the frequency, risk factors and characteristics of PAH in the studied sample.

Methods: It is an echocardiography (echo) based case control study conducted over a 7 months period from the 15th of May to the 14th of December 2019. Information and obtained data were recorded using a special form. Statistical analysis carried out using Microsoft excel 2013 and the statistical package for the social sciences (SPSS) 18 computer programs.

Results: The study involved 76 DS children (mean age in months $19.9 \pm 3.7$ standard error of mean "SEM") and male /female gender ratio of $0.85 / 1$ and 76 NDS children as control group with mean age $9.5 \pm 2.03$ SEM and gender ratio of $0.81 / 1$. Congenital heart diseases were significantly higher among DS group $59 \%$ $(P=0.003)$. The commonest CHD among DS children were CAVC and ASD .The PAH was significantly higher among DS children with high prevalence (30\%) $(P=0.002)$ and odds ratio of $2.48(95 \% \mathrm{Cl} 0.9-6.83)$. Complete atrioventricular canal defect, Patent ductus arteriosus (PDA) and age of $>6$ months were the main risk factors for the development of PAH among DS children.

Conclusion: There is high prevalence of CHDs and their associated PAH among DS children especially in association with CAVC, PDA and age older than 6 months.

Key words: Down syndrome, congenital heart disease, pulmonary arterial hypertension.

$$
\begin{aligned}
& \text { الامراض القلبية الخلقية وارتفاع ضغط الدم الرئوى }
\end{aligned}
$$

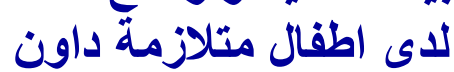

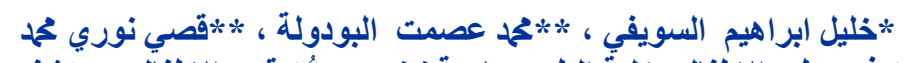

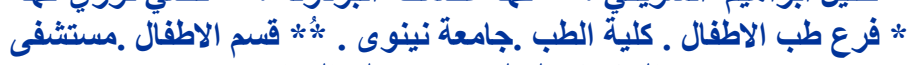

$$
\begin{aligned}
& \text { الخنساء التعليمي .موصل. العراق نينوق }
\end{aligned}
$$

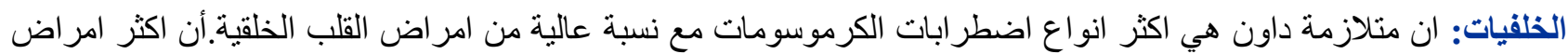

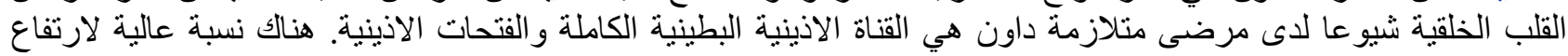

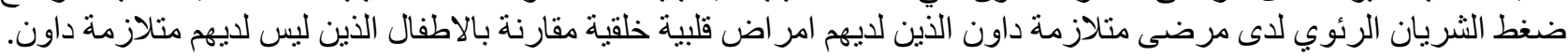

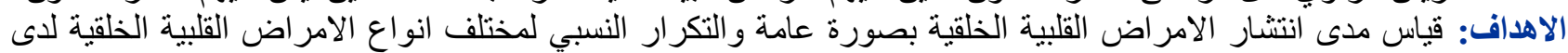

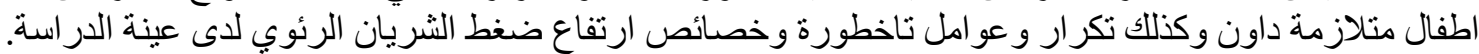

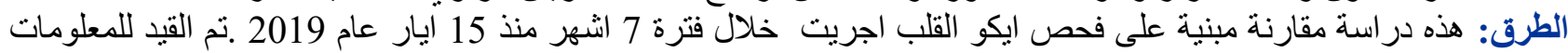

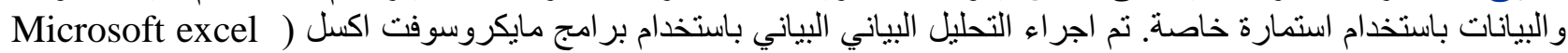
2013) وكذلك برنامج الحزمة الاحصائية للعلوم الاجتماعية التية 18 (SPSS). 


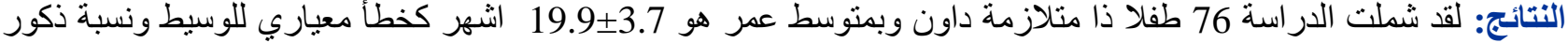

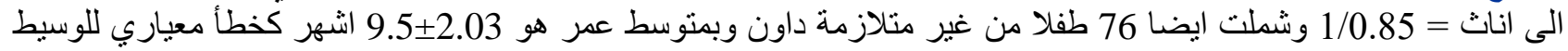

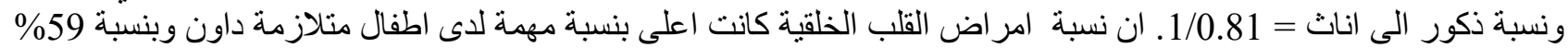

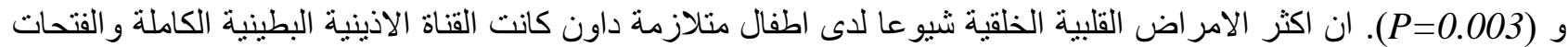

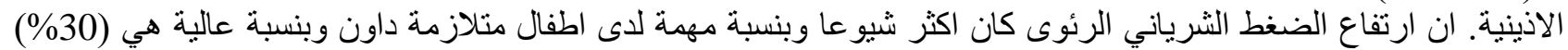

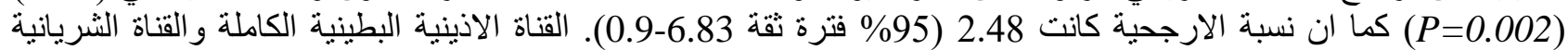
السالكة والعمر الاكبر من 6 اشهر هي عوامل الخطورة الرئيسية التي ساهمت في ارتفاع ضغط الثرة الثريان الرئوي لدى اطفال

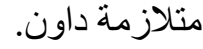
الاستنتاج: هنالك نسبة مرتفعة لامر اض القالب الخلقية وارتفاع الضغط الثرياني الرئوي المرتبط بها لإى اطفال متلازمة داون وبالاخص بالارتباط مع حالات القناة الاذينية البطينية الكاملة والقناة الثريانية السالكة و العمر الاكبر من 6 الشهر.

الكلمات المفتاحية : متلازمة داون، امر اض القلب الخلقية، ارتفاع ضغط الثريان الرئوي.
\end{abstract}

\section{INTRODUCTION}

own syndrome has an incidence of $1 / 700$ live births, $95 \%$ of cases are due to complete trisomy 21 and $5 \%$ of cases are attributed to either chromosomal translocation or mosaicism. This incidence is affected by maternal age and increases to $1 / 30$ live births among mothers who are more than 45 years old. ${ }^{1,2}$

Congenital cardiac defects are found among 40$60 \%$ of DS children and cause an important morbidity and mortality. ${ }^{3-5}$ Atrial septal defects and atrioventricular septal defects are the most frequent types of congenital heart diseases observed among DS children. ${ }^{6-8}$

In case of left to right shunt, the increased pulmonary blood flow leads to elevation in the pulmonary artery pressure, i.e pulmonary arterial hypertension, which is associated with rise in the resistance of pulmonary vasculature. Doppler echocardiography is the primary tool for the evaluation of pulmonary artery pressures. Pulmonary hypertension is classified according to the mean PA pressure (MPAP) into mild (MPAP 25-40 $\mathrm{mmHg}$ ), moderate (MPAP 41-55 mmHg) and severe if the MPAP is $>55 \mathrm{mmHg}$. When the right ventricular pressure reaches or exceeds the left ventricular pressure, Eisemenger's syndrome develops and the shunt will be reversed. The incidence of $\mathrm{PAH}$ complicating $\mathrm{CHD}$ is about $6 \%$, but it is much higher among DS patients (up to $53 \%)$, moreover DS patients constitute (30-45 \%) of all cases of PAH secondary to CHD. All over the world the incidence of $\mathrm{PAH}$ complicating $\mathrm{CHD}$ is declining due to the improved management and early diagnosis of CHD, however DS children remain representing a high risk group for the development of severe PAH early in the course of their CHD. It seems that there is no relation between cytogenic type of DS, patient gender or mental retardation with the type of $\mathrm{CHD}$ or the development of PAH among DS children. ${ }^{9-13}$

\section{AIMS OF THE STUDY}

To measure the prevalence of CHD among pediatric patients with DS in comparison to general population \& to identify the distribution and relative frequency of different types of CHD among them.

To determine the frequency and characteristics of pulmonary arterial hypertension secondary to CHD as well as its risk factors among DS children.

\section{PATIENTS AND METHODS}

This is an a cross sectional (case control) study conducted at the pediatric cardiology and echocardiography unit in the researchers hospital over a 7 months period from the 15th of May 2019.

A total of 152 children under the age of 15 years were enrolled and evaluated non-invasively by clinical examination, chest radiography, electrocardiography (ECG), and transthoracic echocardiography to determine the type of their $\mathrm{CHD}$ and their mean pulmonary artery pressure. Parents' consent were taken for all participants to be enrolled in the study. During the study period a total of 76 children with DS, who consulted the pediatric echo unit for a variety of indications, were evaluated and involved in the study. Every next NDS child came for echo evaluation was taken as a control for the indexed case. Information were collected and recorded using a special questionnaire form. Participants were evaluated echocardiographically by a qualified pediatric cardiologist, using Phillips echocardiography machine with proper pediatric probes, regarding the presence of CHD and its type as well as measurement of the pulmonary artery pressure. CHDs are classified as ventricular septal defect (VSD) with its different types, ASD in its different types, PDA (alone or as a part of association of CHDs), CAVC, Tetralogy of Fallot (TOF), Transposition of great arteries (TGA) or others for the remaining $\mathrm{CHDs}$ because of their 
uncommonness. Pulmonary hypertension was documented as mild when the mean PA pressure was $25-40 \mathrm{mmHg}$, moderate if it was $41-55 \mathrm{mmHg}$, and severe if it was $>55 \mathrm{mmHg}$. Babies with possibly transient problems, like PDA in the first 48 hours were reevaluated 1 week later to confirm its persistence before assigning it as an index case. Obtained data were analyzed using Microsoft excel 2013 and SPSS 18 software packages. P value was calculated by Chi square test and Fisher exact tests for small numbers. $P$ value was considered significant if it was $<0.05$ and highly significant if it was $<0.001$.

\section{RESULTS}

During our study period a total of 548 children were evaluated in our pediatric cardiology unit, 76 $(13.8 \%)$ were DS children. Mean age of DS children was (19.9 \pm 3.7 SEM) months with male to female ratio of $0.85 / 1$, NDS children ( control group) were also 76 in number, their mean age was $(9.5 \pm 2.03$ SEM $)$ months and male to female ratio was $0.81 / 1(P=0.01)$. Children in both groups were from different territories of Nineveh governorate and categorized as urban or rural residents (table 1 ).

As shown in table 2, in general, CHDs were significantly higher $(P=0.003)$ among DS children group with a frequency of $59 \%$ compared to NDS children (35\%). The frequency of different types of CHD was different between both groups, CAVC then ASD and VSD were the most frequent among the DS group in descending frequency, while VSD, PDA and ASD were more frequent among NDS group, however only CAVC was significantly more prevalent among DS group.

Within the DS group, factors like maternal or paternal age being $\leq 35$ or $>35$ years, patient gender and prematurity (delivery before 37 gestational weeks) didn't show significant risk for the development of CHD (table 3).

The frequency of $\mathrm{PAH}$ among children with $\mathrm{CHD}$ in both groups (DS versus NDS, $30 \%$ versus $10.5 \%$ ) was significantly higher among DS group $(P=0.002)$ with Odds ratio of 2.48 and $95 \%$ confidence interval (0.9-6.83). When PAH classified as mild, moderate or severe, there was no significant difference in the mild or severe group, but it was significantly higher in the moderate PAH group $(P=0.03)$ among DS children as seen in table 4 .

As seen in figure 1 , there was a significant risk for the development of PAH among the DS group in association with CAVC and PDA ( $P=0.01$ and 0.02 respectively).

Among the DS group with CHD and PHT, different factors were studied like age, gender, residence, and parental consanguinity to evaluate their relation to the development of $\mathrm{PAH}$, only an age of more than 6 months was significantly contributing to $\mathrm{PAH}$ while the other factors didn't show significant association (table 5).

\section{DISCUSSION}

Congenital heart diseases, which have the highest frequency among all other congenital anomalies, are highly prevalent among DS children and affects $16-62 \%$ of them in different studies. "The American Academy of Pediatrics and the Down Syndrome Medical Interest Group recommends routine neonatal echocardiography, including patients who do not have a heart murmur" 14-17.

The mean age in DS group was significantly higher than in the control group because large of DS children have CHD and need follow up with serial evaluation during their childhood making older patients representing a significant number among the studied sample while the control group were younger because of the higher frequency of presentation with murmurs and symptoms like cyanosis and dyspnea in younger children and neonates. In spite of this difference we don't think that it affected the prevalence of CHD in our study because we are dealing with a congenital rather than acquired problem.

Although CHD is a leading cause of mortality among DS children, this association is not extensively studied in Iraq. We could find 3 prior studies described this association with widely different prevalence of $\mathrm{CHD}$ among DS children from $20 \%$ to $89 \%$. ${ }^{5,7,11,18}$ In our study the prevalence in the studied sample (59\%) was in the mid-range of these previous studies and closer to the world wide prevalence and we think that it is more representative of the weight of the problem. According to our findings and that of other authors ${ }_{1-7}$ there is controversy and variability about gender predilection among DS children in association with the presence of CHD, however our study didn't show significant difference in the gender ratio between DS and control group. Other factors like maternal and/or paternal age being 35 years, type of rsidency or prematurity were not found as significant risk factors to develop CHD in DS group indicating that the genetic problem of DS children is main player in this association.

It is interesting to find a difference in the authors finding about the commonest CHD among DS children. Our finding of CAVC being the most common CHD among DS group and being significantly higher than what is found in the NDS group is supported by other studies $4,8,11,17,18$, while other studies ${ }^{1,2,6,7,14}$ reported ASD as the most common CHD. We think that more studies involving a larger sample of DS children will assist 
in giving decision about this issue. However, it seems that CAVC and ASD are the commonest two cardiac malformation among DS children.

Pulmonary arterial hypertension is the most serious consequence of left to right shunt in congenital cardiac malformations with the possible development of Eisenmenger syndrome as an end result. According to our study DS children have a much higher and significant risk for the development of $\mathrm{PAH}$ secondary to their $\mathrm{CHD}$ in comparison to NDS group (30\% versus $10.5 \%$ ) and for unexplainable reason most cases of DS children $\mathrm{PAH}$ were attributed to the moderate category.

Like our study, Mourato et al and D'Alto et al ${ }^{1,9}$, demonstrated that CAVC was the leading cause of $\mathrm{PAH}$ among DS children. This association of CAVC and $\mathrm{PAH}$ is justified by the greater shunting of blood at both atrial and ventricular levels compared to other CHD. Among DS children with CHD ( $\mathrm{N}=45)$, being older than 6 months in age carries a significant risk for the development of $\mathrm{PAH}$ and time factor regarding the length of time to expose the pulmonary circulation to high blood flow is a possible explanation. Other factors like patient gender, residence, or parental consanguinity seems not to have influence.

The main weak point in this study is the lack of invasive evaluation of the pulmonary artery pressure by cardiac catheterization because of its unavailability in our center, but considering the accuracy of transthoracic echocardiography in assessing the it, this problem did not affect our study results significantly. Another point is the higher mean age of DS group compared to the control one which probably contributed in part to the higher prevalence of $\mathrm{PAH}$ among the DS group.

\section{CONCLUSION}

There is high prevalence of CHD among DS children, in particular CAVC and ASD. The development of $\mathrm{PAH}$ among DS children is early and frequent and needs special attention in the cases of CAVC and PDA in DS children from early infancy. Extensive screening and echocardiographic evaluation for $\mathrm{PAH}$ of all DS children is necessary according to the study findings
Table 1 .Demographic features of DS and NDS children involved in the study.

\begin{tabular}{|l|l|l|}
\hline $\begin{array}{l}\text { Demographic } \\
\text { features }\end{array}$ & $\begin{array}{l}\text { DS children } \\
(\mathrm{n}=76)\end{array}$ & $\begin{array}{l}\text { NDS } \\
\text { children } \\
(\mathrm{n}=76)\end{array}$ \\
\hline Mean age (months) & 19.9 & 9.5 \\
\hline Male /female & $0.85 / 1$ & $0.81 / 1$ \\
\hline $\begin{array}{l}\text { Urban /Rural } \\
\text { residency (\%) }\end{array}$ & 34 & 31.5 \\
\hline
\end{tabular}

There were 76 cases of DS, 45 of cases (59\%) have $\mathrm{CHD}$, while in the control group there were only $27(30 \%)$ cases of the control group (76). Only CAVC was significantly higher among DS children compared to the control group.

Table 2. Frequency of different types of congenital heart disease among Down syndrome and control groups.

\begin{tabular}{|l|l|l|l|}
\hline $\begin{array}{l}\text { Type of } \\
\text { CHD }\end{array}$ & DS(N=76) & NDS(N=76) & $\begin{array}{l}\mathrm{P} \\
\text { value }\end{array}$ \\
\hline CAVC & 11 & 1 & $\mathrm{~S}$ \\
\hline ASD & 9 & 6 & $\mathrm{NS}$ \\
\hline VSD & 8 & 10 & $\mathrm{NS}$ \\
\hline PDA & 7 & 8 & $\mathrm{NS}$ \\
\hline TOF & 3 & 1 & $\mathrm{NS}$ \\
\hline TGA & 2 & 0 & $\mathrm{NS}$ \\
\hline Others & 5 & 1 & NS \\
\hline Total & 45 & 27 & HS \\
\hline
\end{tabular}

CAVC =complete atrioventricular canal, $A S D=$ atrial septal defect, $\mathrm{VSD}=$ ventricular septal defect, $\mathrm{PDA}=$ patent ductus arteriosus, TOF=Tetralogy of Fallot, $\mathrm{TGA}=$ transposition of great arteries, others=other uncommon congenital heart diseases, $S=$ significant, NS =not significant, HS=highly significant. 
Table 3. Risk factors for CHD development in DS group. None of the studied factors showed a significant risk for the development of $\mathrm{CHD}$ among the DS group.

\begin{tabular}{|c|c|c|c|}
\hline Factor & $\begin{array}{l}\text { DS with } \\
\text { CHD } \\
(\mathrm{N}=45)\end{array}$ & $\begin{array}{l}\text { DS } \\
\text { witho } \\
\text { ut } \\
\mathrm{CHD} \\
(\mathrm{N}=3 \\
1)\end{array}$ & $\begin{array}{l}\mathrm{P} \\
\text { value }\end{array}$ \\
\hline \multirow{2}{*}{$\begin{aligned} \text { Maternal age } & \leq 35 \text { years } \\
& >35 \text { years }\end{aligned}$} & 18 & 11 & NS \\
\hline & 27 & 20 & NS \\
\hline \multirow{2}{*}{$\begin{aligned} \text { Paternal age } & \leq 35 \text { years } \\
& >35 \text { years }\end{aligned}$} & 16 & 13 & NS \\
\hline & 29 & 18 & NS \\
\hline \multirow{2}{*}{$\begin{aligned} \text { Patient gender } & \text { Male } \\
& \text { Female }\end{aligned}$} & 21 & 14 & NS \\
\hline & 24 & 17 & NS \\
\hline \multirow{2}{*}{$\begin{array}{ll}\text { Premature } & + \text { ve } \\
\text { delivery (<37 weeks) } & \text {-ve }\end{array}$} & 9 & 3 & NS \\
\hline & 36 & 28 & NS \\
\hline
\end{tabular}

Table 4. Frequency of pulmonary arterial hypertension among Down syndrome and non Down syndrome children. Pulmonary arterial hypertension was a significantly higher among Down syndrome group especially in the moderate severity. DS= Down syndrome, NDS= Non Down syndrome, $\mathrm{PAH}=$ Pulmonary arterial hypertension, $\mathrm{S}=$ significant, $\mathrm{NS}=$ not significant, $\mathrm{HS}=$ highly significant.

\begin{tabular}{|l|l|l|l|}
\hline PAH & $\begin{array}{l}\text { DS } \\
(\mathrm{N}=76)\end{array}$ & $\begin{array}{l}\text { NDS( } \\
\mathrm{N}=76)\end{array}$ & P value \\
\hline MILD & 7 & 6 & $\mathrm{NS}$ \\
\hline MODERATE & 13 & 1 & $\mathrm{~S}$ \\
\hline SEVRE & 3 & 1 & $\mathrm{NS}$ \\
\hline Total & 23 & 8 & $\mathrm{HS}$ \\
\hline
\end{tabular}

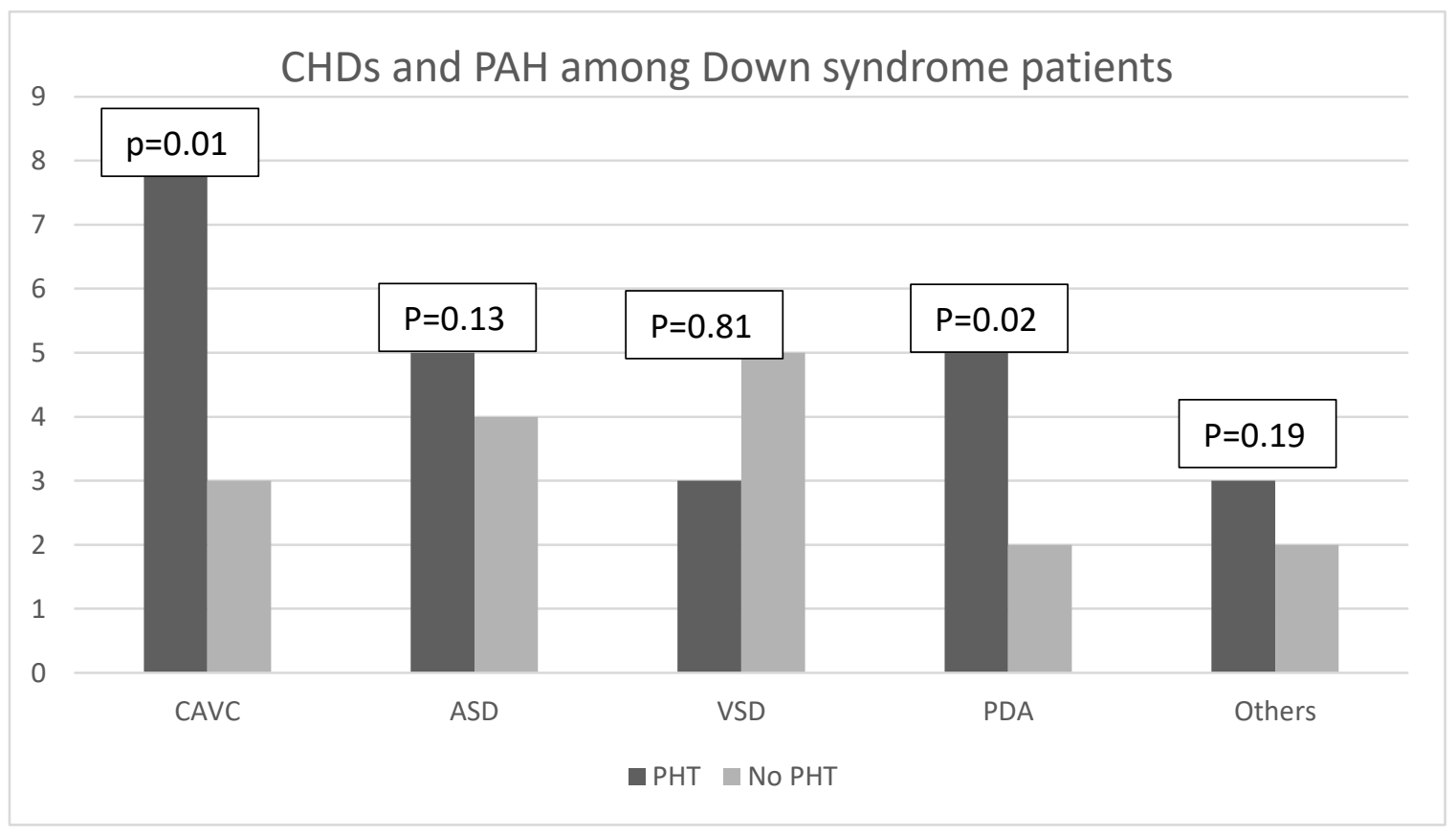

Figure 1. Congenital heart diseases as a cause of pulmonary arterial hypertension. Complete atrioventricular canal patent ductus arteriosus were the main causes of pulmonary arterial hypertension among Down syndrome group. $\mathrm{PAH}=$ Pulmonary arterial hypertension $\mathrm{CAVC}=$ complete atrioventricular canal, $\mathrm{ASD}=$ atrial septal defect, $\mathrm{VSD}=$ ventricular septal defect, $\mathrm{PDA}=$ patent ductus arteriosus 
Table 5. Risk factors for pulmonary arterial hypertension among Down syndrome children. Being older than 6 months is a highly significant risk factor for the development of pulmonary arterial hypertension. PAH= pulmonary arterial hypertension $\mathrm{S}=$ significant, NS =not significant, HS=highly significant.

\begin{tabular}{|c|c|c|c|c|}
\hline Factor & & $\mathrm{PAH}(\mathrm{n}=23)$ & $\begin{array}{c}\text { Non-PAH } \\
(n=22)\end{array}$ & $P$ value \\
\hline \multirow{2}{*}{ Age } & \multirow{2}{*}{$\begin{array}{l}\leq 6 \text { months } \\
>6 \text { months }\end{array}$} & 4 & 15 & NS \\
\hline & & 19 & 7 & $\mathrm{HS}$ \\
\hline \multirow{2}{*}{ Gender } & Male & 9 & 10 & NS \\
\hline & Female & 14 & 12 & NS \\
\hline \multirow{2}{*}{ Residence } & Urban & 13 & 16 & NS \\
\hline & Rural & 10 & 6 & NS \\
\hline \multirow{2}{*}{$\begin{array}{l}\text { Consanguinity of } \\
\text { parents }\end{array}$} & $+\mathrm{ve}$ & 2 & 3 & NS \\
\hline & -ve & 21 & 19 & NS \\
\hline
\end{tabular}

Conflicts of interest :( The authors declare that there is no conflicts of interest regarding the publication of this manuscript).

\section{REFERENCES}

1. Mourato FA, Villachan LR, Mattos Sada S. Prevalence and profile of congenital heart disease and pulmonary hypertension in Down syndrome in a pediatric cardiology service . Rev Paul Pediatr 2014;32(2):159-63.

2. Bermudez BE, Medeiros Sandra Lira, Bagatin $M$, et al . Down syndrome: Prevalence and distribution of congenital heart disease in Brazil. Sao Paulo Med J. 2015; 133(6):521-4.

3. Colvin KL, Yeager ME. What people with Down Syndrome can teach us about cardiopulmonary disease. Eur Respir Rev 2017; 26: 160098.

4. Sica CD, Cesa CC, Pellanda LC. Growth curves in Down syndrome with congenital heart disease. Rev Assoc Med Bras. 2016; 62(5):414-420.

5. Mazin A. Hazza. Congenital heart diseases among patients with Down syndrome consulting cardiology unite in Alsader Teaching Hospital in Basrah. The Medical Journal of Basrah University.2017; Vol. 35, No.1:11-16.
6. ELMAGRPY Z, RAYANI A, SHAH A, HABAS E, ABURAWI EH. Down syndrome and congenital heart disease: why the regional difference as observed in the Libyan experience? Cardiovascular Journal Of Africa .2011 Vol 22, No 6: 306-309.

7. Zaid Moayad Yassen, Mazin Mahmoud Fawzi, Rayan Salim Alsaoor. Frequency of congenital heart disease among patients with Down's syndrome in Mosul. Ann Coll Med Mosul December 2018 Vol. 40 No. 2:24-29.

8. Sanaa Benhaourech, Abdenasser Drighil, Ayoub El Hammiri .Congenital heart disease and Down syndrome: various aspects of a confirmed association. Cardiovascular Journal Of Africa. Volume 27, No 5, September/October 2016: 287-290.

9. Michele D'Alto, Vaikom S. Mahadevan. Pulmonary arterial hypertension associated with congenital heart disease. Eur Respir Rev 2012; 21: 126, 328-337. 
10.Amiram Nir and Neville Berkman. Clinical and Parental Status of Patients with Congenital Heart Disease Associated Pulmonary Arterial Hypertension. IMAJ, volume 19, August 2017:489-493

11.Sabeeha Al-Mefraji. Is any Relation between Cytogenetic types of Down's Syndrome and Congenital Heart Disease. Iraqi J. Comm. Med., Oct. 2012 (4):304-307.

12. Marie M. Budev, Alejandro C. Arroliga, and Constance A. Jennings. Diagnosis and evaluationof pulmonary hypertension. Cleveland Clinic Journal Of Medicine volume 70 - Supplement 1 april 2003: 9-17.

13.Oh Jae K., Seward James B., Tajik, A. Jamil. The Echo Manual, 3rd Edition. Lippincott WIlliams \& Wilkins. 2006. Chapter 9, Pulmonary Hypertension and Pulmonary Vein Stenosis: 144.

14.Ercan Mıhçı, Gayaz Akçurin, Erdal Eren1, Fırat Kardelen, Sema Akçurin, İbrahim Keser, et al. Down syndrome and congenital heart diseases. Anadolu Kardiyol Derg 2010; 10: 440-5 16.

15. American Academy of Pediatrics Committee on Genetics. Health supervision for children with Down syndrome. Pediatrics 2001; 107: 442-9.

16. Espinola-Zavaleta N, Soto ME, RomeroGonzalez A, Gomez-Puente LDC, Castellanos LM, Gopal As et al. Prevalence of Congenital Heart Disease and Pulmonary Hypertension in Down's Syndrome: An Echocardiographic Study. J Cardiovasc Ultrasound 2015;23(2):7277.

17.Brig Mukti Sharma, Maj Sanjeev Khera, Lt Col Vishal Sondhi, and Col Amit Devgan. A study to determine the prevalence of pulmonary arterial hypertension in children with Down syndrome and congenital heart disease. Medical Journal Armed Force India;6 9 ( 2013 ) : $24-245$.

18. Morsy MM, Algrigri OO, Salem SS, Abosedra MM, Aboutaleb AR, Al-Harbi KM,et al. The spectrum of congenital heart diseases in Down syndrome. Saudi Med J 2016; Vol. 37 (7):76772. 